\title{
The Development of Spiritual Values Integrated Innovative Chemistry Practical Guidance with Inquiry Model for Senior High School Students
}

\author{
Rabiah Afifah Daulay \\ Chemical Education Postgraduate \\ Universitas Negeri Medan \\ Medan, Indonesia \\ Corresponding Email: rad.chemistry.08@gmail.com
}

\author{
Ayi Darmana \\ Chemical Education Postgraduate \\ Universitas Negeri Medan \\ Medan, Indonesia
}

\author{
Marham Sitorus \\ Chemical Education Postgraduate \\ Universitas Negeri Medan \\ Medan, Indonesia
}

\begin{abstract}
This research aims to know: (1) There are integrating spiritual values on chemistry practical guidance based on 2013 Curriculum; (2) The feasibility of an innovative chemistry practical guidance that have been developed for 11th grade senior high school student at odd semester. The method used is Research and Development ( $R$ and $D)$ which is using Dick and Carey development design. It was adapted to this research become four stages, namely (1) needs analysis stage was conducted by examine the $\mathbf{2 0 1 3}$ curriculum and study directly on the chemistry lab guide that has been in circulation.; (2) design product stage which was conducted by practical guiding components, spiritual values, evaluation questions, and practice guide layouts; (3) product evaluation stage, the product has been validated by 10 teachers and 2 lecturers, they conduct an assessment of practical guidance and spiritual value feasibility and (4) and final product steps obtained a chemistry practical guidance using for $11^{\text {th }}$ grade senior high school student at odd semester. The result of the test is validated by a lecturer and ten teachers which reached the average score of 4,48 eligibility of content and 3,91 of spiritual values integrated.
\end{abstract}

Keywords-Research and Development, Chemistry Practical Guidance, Spiritual Values

\section{INTRODUCTION}

The fact that the purpose of education is still not fully realized, especially in terms of moral quality and attitude. this can be known based on national population and family planning board's statistical data (BKKBN) showing the number of juvenile delinquency is still high in 2014, including $46 \%$ of teenagers (aged 14-16 years) in indonesia claiming to have had sex outside of marriage, $33 \%$ of abortionists in Indonesia are teenager 3.2 million teenager are involved in drug abuse cases (National Population and Family Planning Board, 2014)
Education based on 2013 curriculum only aims at achieving core competencies attitudes, knowledge and skills that can be measured by tests. Whereas spiritual core competencies did not receive attention from educators, according to Darmansyah (2014) that spiritual core competencies have not received adequate proportions in learning.

The shift in time and development of thought between religion and science resulted in the two as if separated. Religion without the support of science can become rooted in reality and reasoning. Whereas science that is not based on the basics of religious science will develop into a wild and destructive impact (Purwaningrum, 2015). Therefore the integration of science (science) and religious science (Islamic science) is something that is very urgent to achieve the mandate of the national education goals.

The existence of spiritual competence in learning is expected to be able to become a good human being towards the values of his religious teachings, which is reflected in the increasing social competence and learning outcomes of students. Aditama (2016) has researched the development of integrated science textbooks in the verses of Al-Quran on the material of the movement of the sun, earth, and the moon for the eighth grade of SMP / MTs showing the results that the completeness of student learning outcomes is $100 \%$ for skill competencies and 93, 33\% for knowledge competencies. The percentage of completeness shows the effectiveness of very good textbooks. These results are also supported by the percentage of positive responses of students and teachers to textbooks, which amounted to $99.09 \%$ and $96.43 \%$. Darmana (2013) examined the views of students on the internalization of the value of monotheism through thermochemical material showing that the results were very positive with an average score of $87.2 \%$. 
The general fact that practicum conducted in schools has not provided experience to students to make hypotheses, test the truth and analyze data. This is because the practicum procedure used generally contains direct instructions. Students work on the steps according to the instructions. In addition, practicum activities carried out have not provided an opportunity for students to actively participate in practicing (Jannah, 2012).

Based on the analysis of the documents that have been carried out, it was found that the circulation of the practicum guide book based on the 2013 Curriculum was very minimal in number, with only one entitled The Handbook of Chemical Experiments published by PT. Datesa Prima Catalyst. Needs analysis of the practicum guide book based on 2013 curriculum also does not meet the criteria because there are no spiritual values in it, there are only three other aspects, namely social, knowledge and skills.

\section{METHOD}

The type of this research is Research and Development. The development model used was Dick and Carey modified to be four stages, there are needs analysis, product design, evaluation, product that has been tested.

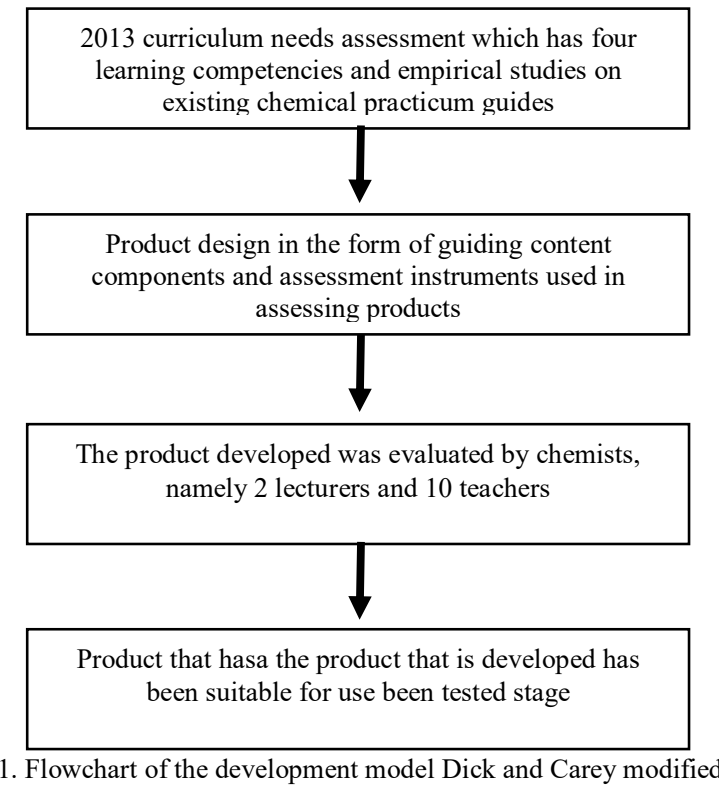

Fig 1. Flowchart of the development model Dick and Carey modified

The book analyzed was a chemistry class XI high school practicum guide that was widely circulated by publishers of Datesa Prima, Erlangga, and Bumi Aksara Catalysts. The validator of the practicum guide that has been developed is two lecturers with the last doctoral education in the chemistry department of Universitas Negeri Medan And then 10 chemistry teachers in MAN of Medan.

Integration of spiritual values is by using Al-Quran verses relating to the subject of chemistry. The practicum guide that was developed was assessed based on two feasibility standards according to Curriculum 13 namely the feasibility of the content and the feasibility of the presentation. Assessment is done by giving a response in the form of a check list with a rating order that is $1=$ very improper, $2=$ not feasible, $3=$ feasible, $4=$ feasible, $5=$ very feasible. The integration of the Al-Quran verses into the chemical practicum guide was carried out by distributing questionnaires to assess the validity of spiritual values to the validator. The assessment questionnaire uses a Likert scale with a scale of 4 .

\section{RESULT AND DISCUSSION}

After analyzing the three different practicum guides that are part of the needs analysis phase, the product design stage is carried out. At this stage, the first step is to describe the indicators based on core competencies and basic competencies in the 2013 curriculum. Next, design the chemistry practicum materials by finding and adjusting the verses of the Al-Quran relating to the related material to be integrated in the practicum guide developed.

The material developed in the form of practical guide in accordance with the 2013 curriculum syllabus there are $9 \mathrm{KD}$ which are divided into four topics, namely hydrocarbons and petroleum, thermochemistry, reaction rates, and chemical equilibrium. Basic competencies for odd semester are 9, but only 7 basic competencies contained in the practicum guide are developed due to the limitations of researchers in finding verses of the Al-Quran relating to chemical material.

\begin{tabular}{|c|c|c|c|}
\hline No & Subject Matter & $\begin{array}{l}\text { Experimental } \\
\text { Title }\end{array}$ & $\begin{array}{l}\text { Verse of the Qur'an } \\
\text { which is integrated }\end{array}$ \\
\hline 1 & Hydrocarbon & $\begin{array}{l}\text { Determination of } \\
\text { carbon compounds } \\
\text { in sugar }\end{array}$ & $\begin{array}{l}\text { Q.S.Al-Furqaan (25):2 } \\
\text { Q.S.Al-A'la (87):1-2 }\end{array}$ \\
\hline 2 & Thermochemistry & $\begin{array}{l}\text { exothermic and } \\
\text { endothermic } \\
\text { reactions }\end{array}$ & Q.S.Al-Zalzalah (99):7-8 \\
\hline 3 & & Enthalpy changes & Q.S.Yunus(10):5 \\
\hline 4 & Reaction rate & Reaction rate & $\begin{array}{l}\text { Q.S.Al-Anbiyaa' (21):30 } \\
\text { Q.S.Fussilat (41):11 }\end{array}$ \\
\hline 5 & Reaction rate & $\begin{array}{lr}\text { Factors } & \text { that } \\
\text { influence } & \text { the } \\
\text { reaction rate } & \end{array}$ & Q.S.An-Nahl (16):13 \\
\hline 6 & $\begin{array}{l}\text { Chemical } \\
\text { Equilibrium }\end{array}$ & $\begin{array}{l}\text { Rreversible } \\
\text { reaction }\end{array}$ & Q.S.An-Nur (24):43 \\
\hline
\end{tabular}

Experimental activities are arranged with the steps of the inquiry learning model syntax. The practicum guide that was developed presents several components including: laboratory discipline, occupational health and safety, symbol of hazardous chemicals, occupational safety equipment, laboratory tools and their uses, true-false use of laboratory equipment, laboratory waste management, seven experimental titles, material safety data shees, glossary, bibliography.

\section{A. Feasibility Assessment of the Content of an Innovative Chemistry Practicum Guide}

Validator's assessment of the practicum guide developed based on the contents feasibility can be seen in table 2 . 
TABLE 2. Feasibility Assessment Of The Content

\begin{tabular}{lcccc}
\hline \multicolumn{1}{c}{$\begin{array}{c}\text { The content of } \\
\text { feasibility indicator }\end{array}$} & $\begin{array}{c}\text { Lecturer } \\
(\mathrm{n}=2)\end{array}$ & $\begin{array}{c}\text { Teacher } \\
(\mathrm{n}=10)\end{array}$ & Mean & Exp. \\
\hline Practical suitability & 4,5 & 4,0 & 4,25 & $\begin{array}{c}\text { Very } \\
\text { feasible }\end{array}$ \\
\hline Practice objectives & 4,5 & 4,8 & 4,62 & $\begin{array}{c}\text { Very } \\
\text { feasible }\end{array}$ \\
\hline Basic theory & 4,5 & 4,5 & 4,45 & $\begin{array}{c}\text { Very } \\
\text { feasible }\end{array}$ \\
\hline Practical tools & 4,0 & 4,6 & 4,30 & $\begin{array}{c}\text { Very } \\
\text { feasible }\end{array}$ \\
\hline Practicum material & 4,0 & 4,9 & 4,45 & $\begin{array}{c}\text { Very } \\
\text { feasible }\end{array}$ \\
\hline Practical procedure & 4,5 & 4,9 & 4,70 & $\begin{array}{c}\text { Very } \\
\text { feasible }\end{array}$ \\
\hline Observation table & 4,5 & 4,7 & 4,60 & $\begin{array}{c}\text { Very } \\
\text { feasible }\end{array}$ \\
\hline $\begin{array}{l}\text { Conformity with } \\
\text { inquiry learning } \\
\text { models }\end{array}$ & 4,0 & 4,9 & 4,45 & $\begin{array}{c}\text { Very } \\
\text { feasible }\end{array}$ \\
\hline
\end{tabular}

\section{B. Feasibility Assessment of the Presentation of the Guide to Innovative Chemistry Practicum}

Validator's assessment of the practicum guide developed based on the presentation feasibility can be seen in table 3 .

TABLE 3. Feasibility Assessment Of The Presentation

\begin{tabular}{lcccc}
\hline $\begin{array}{l}\text { The presentation of } \\
\text { feasibility indicator }\end{array}$ & $\begin{array}{c}\text { Lecturer } \\
(\mathrm{n}=2)\end{array}$ & $\begin{array}{c}\text { Teacher } \\
(\mathrm{n}=10)\end{array}$ & Mean & Exp. \\
\hline $\begin{array}{l}\text { Systematic } \\
\text { consistency }\end{array}$ & 5,0 & 5,0 & 5,00 & $\begin{array}{c}\text { Very } \\
\text { feasible }\end{array}$ \\
\hline Glossary & 4,5 & 5,0 & 4,75 & $\begin{array}{c}\text { Very } \\
\text { feasible }\end{array}$ \\
\hline $\begin{array}{l}\text { Accuracy of sentence } \\
\text { structure }\end{array}$ & 4,5 & 5,0 & 4,75 & $\begin{array}{c}\text { Very } \\
\text { feasible }\end{array}$ \\
\hline Use of terms, symbols & 4,5 & 4,8 & 4,65 & $\begin{array}{c}\text { Very } \\
\text { feasible }\end{array}$ \\
\hline Bibliography & 5,0 & 5,0 & 5,00 & $\begin{array}{c}\text { Very } \\
\text { feasible }\end{array}$ \\
\hline $\begin{array}{l}\text { General guidelines in } \\
\text { the laboratory }\end{array}$ & 5,0 & 5,0 & 5,00 & $\begin{array}{c}\text { Very } \\
\text { feasible }\end{array}$ \\
\hline Student-centered & 4,5 & 5,0 & 4,75 & $\begin{array}{c}\text { Very } \\
\text { feasible }\end{array}$ \\
\hline Cover illustration & 4,0 & 4,8 & 4,40 & $\begin{array}{c}\text { Very } \\
\text { feasible }\end{array}$ \\
\hline
\end{tabular}

\section{Feasibility Assessment of Al-Quran Integrated}

Validator's assessment of the practicum guide developed based on the Al-Quran integrated can be seen in table 4.
TABLE 4. Feasibility Assessment Of Integration

\begin{tabular}{|c|c|c|}
\hline Assessment & Mean & Exp. \\
\hline $\begin{array}{l}\text { Write the basmalah and hamdalah } \\
\text { sentences }\end{array}$ & 4,00 & $\begin{array}{l}\text { Very } \\
\text { feasible }\end{array}$ \\
\hline $\begin{array}{l}\text { Integrating the concept of spiritual } \\
\text { values that will be discussed with } \\
\text { quotations from related Al-Quran } \\
\text { verses }\end{array}$ & 4,0 & $\begin{array}{c}\text { Very } \\
\text { feasible }\end{array}$ \\
\hline $\begin{array}{l}\text { Explain the meaning of quotations from } \\
\text { Al-Quran verses and are related to the } \\
\text { practicum that has been done }\end{array}$ & 4,0 & $\begin{array}{c}\text { Very } \\
\text { feasible }\end{array}$ \\
\hline $\begin{array}{l}\text { Provide a reflection explanation related } \\
\text { to the practicum that has been done so } \\
\text { that it can encourage the formation of } \\
\text { awareness and glorification of God's } \\
\text { greatness }\end{array}$ & 4,0 & $\begin{array}{c}\text { Very } \\
\text { feasible }\end{array}$ \\
\hline $\begin{array}{l}\text { Inserting aphorisms derived from the } \\
\text { hadiths of the Prophet Muhammad saw } \\
\text { related to the practicum that has been } \\
\text { carried out }\end{array}$ & 3,65 & $\begin{array}{c}\text { Very } \\
\text { feasible }\end{array}$ \\
\hline
\end{tabular}

\section{CONCLUSION}

Innovative chemistry practical guide, integrated inquiry model of 2013 curriculum-based spiritual values for senior high school students including valid categories means that it is very feasible and does not need to be revised with an average value of 4.6 covering the content and feasibility of presentation. While the integration of the verses into the practicum guide is included in the valid category an average value of 3.93 means that it is very feasible and does not need revision.

\section{REFERENCES}

[1] Aditama. Rizky (2016) Pengembangan Buku Ajar IPA Terintegrasi Ayat-Ayat Al-Quran pada Materi Pergerakan Matahari, Bumi, dan Bulan Untuk Kelas VIII SMP/MTs.Jurnal Inovasi Pendidikan Fisika5(2),89-93

[2] BkkbN (2014) Fenomena Kenakalan Remaja di Indonesia, (Online), (http://ntb.bkkbn.go.id/lists/artikel/dispform.aspx?id=673\&contenttypeid $=0 \times 0 /$, diakses 1 September 2016).

[3] Darmana. Ayi (2012) Internalisasi Nilai Tauhid dalam Pembelajaran Sains. Jurnal Pendidikan Islam17(1):66-84

[4] Darmana. Ayi (2013) Pandangan Peserta didik terhadap Internalisasi Nilai Tauhid melalui Materi Termokimia serta perlunya dalam Materi Pelajaran IPA. Jurnal Penelitian Bidang Pendidikan19(2):87-97

[5] Darmansyah (2014) Teknik Penilaian Sikap Spiritual dalam Pendidikan Karakter Di Sekolah Dasar 08 Surau Gadang Nanggalo, Jurnal AlTa'lim 21(1): 10-17

[6] Jannah. M, Sugianto (2012)Pengembangan Perangkat Pembelajaran Berorientasi Nilai Karakter Melalui Inkuiri Terbimbing Materi Cahaya pada Peserta didik Kelas VIII Sekolah Menengah Pertama. Journal of Innovative Science Education1(1):54-56

[7] Purwaningrum. Septiana (2015) Elaborasi Ayat-Ayat Sains dalam AlQuran: Langkah Menuju Integrasi Agama dan Sains dalam Pendidikan. Jurnal Penelitian Pendidikan, Agama, dan Kebudayaan1(1):124-14 